\title{
1: 1854657-1748892
}

National Cancer Institute

\section{Source}

National Cancer Institute. 1:1854657-1748892. NCI Thesaurus. Code C42396.

Physical location of GNB1_Gene 